\title{
DEMOKRASI DAN PENERAPANNYA
}

\author{
Nikmatul Khusna \\ IIK STRADA INDONESIA \\ nikmatulkhusna@gmail.com
}

\begin{abstract}
ABSTRAK
Demokrasi merupakan nilai universal sebagai kehendak rakyat yang diekspresikan secara bebas untuk menentukan sistem politik, ekonomi, sosial, dan budaya. Secara sederhana, demokrasi digambarkan sebagai "pemerintahan dari rakyat, oleh rakyat, dan untuk rakyat". Pada hakekatnya demokrasi diwujudkan untuk mencapai kemakmuran.

Demokrasi merupakan konsep pemerintahan yang bermula dari konsep yang dijalankan di polis Athena pada masa Yunani kuno. Konsep tersebut sempat terkubur lama tetapi kembali menemukan jalankan seiring berakhirnya abad pertengahan di Eropa. Demokrasi makin berkembang dan dianggap sebagai sistem yang paling baik. Ide demokrasi telah merasuk ke Indonesia sejak negeri masih menjadi negeri jajahan. Sekelompok kecil pemuda Indonesia yang menjadi saksi perkembangan demokrasi di Eropa mencuri ide demokrasi dan membawanya ke tanah air.
\end{abstract}

\section{LATAR BELAKANG}

Demokrasi adalah bentuk pemerintahan di mana semua warga negaranya memiliki hak yang sama pengambilan keputusan yang dapat mengubah hidup mereka. Demokrasi mengizinkan warga negara berpartisipasi baik secara langsung atau melalui perwakilan dalam perumusan, pengembangan, dan pembuatan hukum. Demokrasi mencakup kondisi sosial, ekonomi, dan budaya yang memungkinkan adanya praktik kebebasan politik secara bebas dan setara. Demokrasi juga merupakan seperangkat gagasan dan prinsip tentang kebebasan beserta praktik dan prosedurnya. Demokrasi mengandung makna penghargaan terhadap harkat dan martabat manusia.

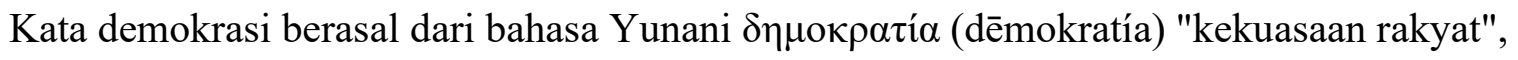

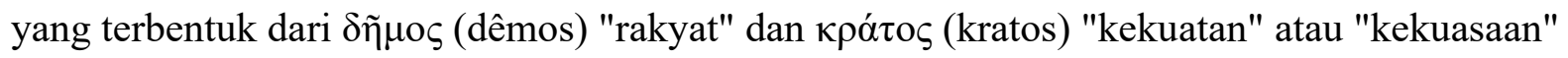
pada abad ke-5 SM untuk menyebut sistem politik negara-kota Yunani, salah satunya Athena;

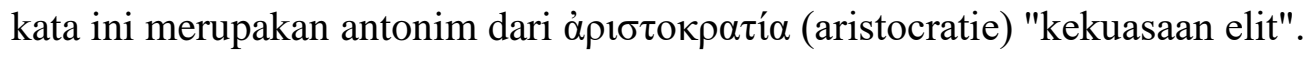


Demokrasi merupakan konsep pemerintahan yang bermula dari konsep yang dijalankan di polis Athena pada masa Yunani kuno. Konsep tersebut sempat terkubur lama tetapi kembali menemukan jalankan seiring berakhirnya abad pertengahan di Eropa. Demokrasi makin berkembang dan dianggap sebagai sistem yang paling baik. Ide demokrasi telah merasuk ke Indonesia sejak negeri masih menjadi negeri jajahan. Sekelompok kecil pemuda Indonesia yang menjadi saksi perkembangan demokrasi di Eropa mencuri ide demokrasi dan membawanya ke tanah air. Demokrasi kemudian terus mengalami pergumulan dengan cita-cita kemerdekaan. Setelah Indonesia merdeka pergumulan tersebut terus berlanjut. Demokrasi mencari bentuknya melalui jalan yang tidak mudah. Negeri ini mengalami percobaan-percobaan pelaksanaan demokrasi. Sistem demokrasi parlementer yang pada mulanya dianut akhirnya harus jatuh karena fragmentasi politik yang keras. Indonesia lalu menganut demokrasi terpimpin. Suatu konsep yang konon merupakan konsep asli Indonesia tetapi mendapat kritik keras dari banyak pihak dan salah satunya adalah mantan wakil presiden Mohammad Hatta.

\section{KASUS ATAU MASALAH}

1. Bagaimana cara kita menerapkan demokrasi?

2. Dampak dari demokrasi?

\section{TINJAUAN PUSTAKA}

Indonesia memasuki babak baru yang seringkali disebut masa Demokrasi Parlementer. Pada masa ini nyatanya jatuh bangun kabinet masih saja terjadi. Tidak ada kabinet yang mampu bertahan sampai dua tahun. Namun ada juga capaian yang patut dibanggakan yaitu pemilu tahun 1955. Sebuah pemilu yang dikenang sebagai salah satu pemilu paling demokratis sepanjang sejarah Indonesia. Setelah pemilu itulah parlemen yang sebenarnya baru terbentuk. Parlemen hasil pemilu ini ternyata juga cukup beragam dan seringkali terjadi pertentangan yang keras. Kabinet-kabinet masih juga tidak berusia panjang.11 Menurut Hatta kemelut ini dipicu oleh hasrat "berbagi rezeki" dan mengutamakan golongan sendiri. Golongan, partai, telah jatuh sebagai tujuan bukan kendaraan atau alat untuk melangsungkan kehidupan bernegara demi tercapainya tujuan negara.12 Sementara itu UUD 1950 yang bersifat sementara nyatanya berlangsung hampir selama sepuluh tahun. Konstituante sebagai badan yang dibentuk berdasarkan kekuatan partai hasil pemilu untuk menyusun undang-unadng dasar yang baru tak kunjung menyelesaikan tugasnya.

\section{PENJELASAN}


Demokrasi merupakan sistem pemerintahan yang di dalamnya selalu melibatkan rakyat dalam setiap pembuatan hukum suatu negara. Kamu mungkin sudah tidak asing dengan hakikat demokrasi, yaitu pemerintahan dari rakyat, oleh rakyat, dan untuk rakyat. Demokrasi mengizinkan warga negara untuk berpartisipasi, baik secara langsung atau melalui perwakilan dalam perumusan, pengembangan, dan pembuatan hukum. Negara yang menganut sistem demokrasi akan memberikan kebebasan untuk warga negaranya menyampaikan pendapat.

Jenis-jenis demokrasi yang ada di dunia:

1. Demokrasi langsung (direct democracy)

Demokrasi langsung adalah ketika warga negara dapat memilih kebijakan secara langsung tanpa perantara atau majelis parlemen. Jika pemerintah harus mengesahkan undang-undang atau kebijakan tertentu, diserahkan pada rakyat.

2. Demokrasi tak langsung atau representatif (indirect atau representative democracy)

Demokrasi tak langsung atau demokrasi representatif adalah ketika orang memilih perwakilan untuk duduk di parlemen. Bentuk demokrasi ini paling umum ditemukan di seluruh dunia.

3. Demokrasi presidensial (presidential democracy)

Melalui demokrasi presidensial, presiden suatu negara memiliki sejumlah besar kekuasaan atas pemerintah. Presiden dipilih secara langsung atau tidak langsung oleh warga negara.

4. Demokrasi parlementer (parliamentary democracy)

Dalam demokrasi parlementer kedudukan lembaga legislatif lebih kuat. Lembaga eksekutif memperoleh legitimasi demokrasi hanya dari legislatif yaitu parlemen.

5. Demokrasi otoriter (authoritarian democracy)

Demokrasi otoriter terjadi ketika hanya elit yang merupakan bagian dari proses parlementer. individu-individu tertentu diizinkan memilih kandidat tetapi orang biasa tidak dapat.

6. Demokrasi partisipatif (participatory democracy)

Demokrasi partisipatif adalah kebalikan demokrasi otoriter. Ada berbagai jenis demokrasi partisipatif tetapi semuanya sama yaitu untuk menciptakan 
peluang bagi semua anggota populasi untuk memberikan kontribusi dalam proses pengambilan keputusan.

7. Demokrasi Islam (Islamic democracy)

Bentuk demokrasi ini berupaya menerapkan hukum Islam ke dalam kebijakan publik dengan tetap mempertahankan kerangka demokrasi. Demokrasi Islam memiliki tiga karakteristik utama yaitu:

- Para pemimpin dipilih oleh rakyat.

- Semua orang tunduk pada hukum Syariah, termasuk para pemimpin.

- Para pemimpin harus berkomitmen mempraktikkan syura.

\section{Demokrasi sosial (social democracy)}

Demokrasi sosial muncul sebagai reaksi terhadap kebijakan neoliberal dalam ekonomi internasional. Demokrasi sosial bertujuan memberdayakan negara atas pasar neoliberal. Pengeluaran negara untuk memberikan layanan gratis daripada swasta yang terlalu mahal.

Dampak-dampak terjadinya demokrasi:

1. Rakyat bebas bersuara

2. Peran serta musyawarah semakin terasa

3. Tidak ada lagi pemerintah otoriter

4. Dibelinya suara rakyat

5. Adanya demo berlebihan

\section{KESIMPULAN}

Pada dasarnya demokrasi sangat penting untuk kelangsungan Negara. Karena, dengan adanya demokrasi system pemerintahan akan dijalankan dimana warga Negara langsung menggunakan kekuasaannya.

Penerapan demokrasi di kehidupan sehari-hari, bisa dengan cara :

1. Menggunakan Kebebasan dengan bertanggung jawab

2. Membiasakan taat kepada aturan.

3. Lebih mengutamakan persatuan dan kesatuan nasional.

4. Menjunjung tinggi persamaan.

5. Membiasakan diri menyalurkan aspirasi secara damai.

Ada juga saran agar terjalannya demokrasi di Indonesia semakin lancer:

1. Pelaksanaan Demokrasi Pancasila di Indonesia ini harus benar-benar berjalan Luber dan jurdil. 
2. Pelaksanaan pemilu yang merupakan salah satu bentuk Demokrasi, harus berjalan sesua konsep-konsep demokrasi itu sendiri.

3. Pemerintah pusat dan daerah harus tegas dalam menjalankan sistem demokrasi di Indonesia.

4. Bagi masyarakat Indonesia yang juga melaksanakan sistem demokrasi juga harus jujur dan adil.

\section{DAFTAR PUSTAKA}

Siregar, R. B. (2015). PEMIKIRAN DEMOKRASI PANCASILA MENURUT AKBAR TANDJUNG (Doctoral dissertation, UNIMED).

Kurniawan, D. (2016). Demokrasi Indonesia dalam Lintasan Sejarah Yang Nyata dan Yang Seharusnya. MOZAIK: Jurnal Ilmu-Ilmu Sosial dan Humaniora, 8(1).

https://www.kompas.com/skola/read/2020/01/29/200000069/8-jenis-demokrasi-di-dunia https://hukamnas.com/dampak-positif-dan-negatif-demokrasi

Siyoto, S., \& Sodik, M. A. (2015). Dasar metodologi penelitian. Literasi Media Publishing.

KHUSNA, N. (2021). HUBUNGAN BUDAYA DENGAN KESATUAN DAN PERSATUAN INDONESIA.

KHUSNA, N. (2021). Peran Masyarakat dan Orang Tua Dalam Edukasi Seks Pada Anak. 